\title{
Upper Limb Functionality and Quality of Life in Women with Five-Year Survival after Breast Cancer Surgery
}

\section{Funcionalidade do membro superior e qualidade de vida em pacientes com sobrevida de cinco anos após tratamento cirúrgico para câncer de mama}

\author{
Thaís Lunardi Recchia ${ }^{1} \quad$ Amably Cristiny Prim ${ }^{1} \quad$ Clarissa Medeiros da Luz ${ }^{1}$ \\ ${ }^{1}$ Centro de Ciências da Saúde e do Esporte, Universidade do Estado de \\ Santa Catarina (UDESC), Florianópolis, SC, Brasil \\ Rev Bras Ginecol Obstet 2017;39:115-122. \\ Address for correspondence Clarissa Medeiros da Luz, PhD, Programa \\ de Pós-Graduação em Fisioterapia da Universidade do Estado de Santa \\ Catarina (UDESC), 88080-350-Florianópolis/SC, Brasil \\ (e-mail: amablyfisio@gmail.com; Ir_thais@yahoo.com.br).
}

\begin{abstract}
Keywords

- mastectomy

- range of motion

- quality of life

- upper limb functionality

Objective To evaluate the correlation between upper limb functionality and quality of life in women with five-year survival following breast cancer surgical treatment. The secondary objective was to evaluate the function of the ipsilateral upper limb and the quality of life in relation to the type of surgery and the presence of pain.

Methods The Disabilities of Arm, Shoulder and Hand (DASH), and the Functional Assessment of Cancer Therapy - Breast plus Arm Morbidity (FACTB + 4) questionnaires were used to evaluate upper limb function and quality of life respectively. Data distribution was verified by the Shapiro-Wilk test. Pearson's correlation coefficient was used for the parametric variables, and Spearman's rank correlation coefficient was used for the distribution of non-parametric variables. The statistical significance was set at $5 \%(p<0.05)$.

Results The study included 30 patients, with a mean age of $51.23( \pm 8.72)$ years. The most common complications were: pain (50\%), adherence (33.3\%), and nerve lesion (20.0\%). There was a moderate negative correlation between the instruments DASH and FACTB +4 (total score), $r=-0.634$, and a strong negative correlation between the DASH and the FACTB +4 arm subscale, $r=-0.829$. The scores of both questionnaires showed significant difference on the manifestation of pain. However, there was no significant difference found when comparing the scores considering the type of surgery performed.

Conclusions Five years after surgery, the patients showed regular functionality levels on the ipsilateral upper limb and decreased quality of life, especially in the group manifesting pain.
\end{abstract}

received

March 1, 2016

accepted

August 11, 2016

published online

February 23, 2017
DOI http://dx.doi.org/

10.1055/s-0037-1598642.

ISSN 0100-7203.
Copyright $(2017$ by Thieme-Revinter

Publicações Ltda, Rio de Janeiro, Brazil
License terms

(ㄷ) (i) $\ominus$ (5) 


\section{Resumo}

\section{Palavras-chave}

- mastectomia

- amplitude de movimento articular

- qualidade de vida

- funcionalidade de membro superior
Objetivo Avaliar se há correlação entre a funcionalidade e a qualidade de vida em pacientes com sobrevida de cinco anos submetidas ao tratamento cirúrgico para câncer de mama e, secundariamente, avaliar a função do membro superior homolateral à cirurgia, e a qualidade de vida em função do tipo de cirurgia mamária e da presença de dor.

Métodos Foram utilizados os questionários DASH e FACTB + 4 para avaliar a função do membro superior e a qualidade de vida respectivamente. Os dados foram submetidos ao teste de normalidade de Shapiro-Wilk. O coeficiente de correlação de Pearson foi utilizado para as variáveis com distribuição paramétrica e, para as variáveis com distribuição não paramétrica, o coeficiente de correlação de Spearman. Adotou-se o nível de significância de $5 \%(p<0,05)$.

Resultados Foram incluídas 30 pacientes, com média de idade de 51,23 ( $\pm 8,72)$ anos. As complicações mais incidentes foram: dor (50\%), aderência cicatricial $(33,3 \%)$, e lesão nervosa $(20,0 \%)$. Foi observada correlação negativa de magnitude moderada entre os instrumentos DASH e FACTB +4 (pontuação total), $r=-0,634$, e de magnitude forte entre o DASH e a subescala braço do FACTB $+4, r=-0,829$. As pontuações dos questionários apresentaram diferença significativa em função da presença de dor. Entretanto, não foi observada diferença significativa quando comparadas as pontuações com relação ao tipo de cirurgia.

Conclusões Após cinco anos de cirurgia, as pacientes apresentaram grau regular de funcionalidade do membro homolateral à cirurgia e diminuição na qualidade de vida relacionada à saúde, principalmente no grupo que relatava presença de dor.

\section{Introduction}

Breast cancer (BC) is currently the neoplasm with the highest incidence and is the most common cause of cancer-related deaths among women worldwide. ${ }^{1,2}$ In Brazil, it represents the second leading cancer-related cause of death among women, after non-melanoma skin carcinoma. ${ }^{3}$ Between the years 2014 and 2015, there was an estimated 57,120 new cases in Brazil, which represents an incidence of 56.1 cases per 100,000 women. ${ }^{4}$

The primary treatment choice for $\mathrm{BC}$ is surgery (radical or conservative), and the other options are radiation, chemotherapy, hormonal therapy and targeted therapy as adjuvant treatments. ${ }^{5}$ Despite the advances in surgical techniques, the procedure is still associated with a high prevalence of complications on the ipsilateral upper limb, and more than half of the patients who undergo axillary clearance present post-surgery comorbidities. ${ }^{6}$

The main complications related to surgery are sensitivity impairment, seroma production, altered ventilatory capacity, lymphedema, axillary cording, reduced strength on the upper limb, reduced range of motion (ROM) of the arm and shoulder, and pain. ${ }^{7,8}$ Pain itself is the main physical/functional impairment reported by patients, ${ }^{9}$ with a prevalence of up to $60 \% .^{9,10}$

Functionality involves the interrelation of the personal aspects of an individual (physical and emotional) with the surroundings (the environment and the engagement on activities). ${ }^{11}$ The morbidities resulting from $\mathrm{BC}$ treatment create a negative impact on upper limb functionality, affecting daily activities; when added to altered body image and emotional disturbances such as anxiety and depression, that can affect the quality of life of women who have undergone treatment. ${ }^{12,13}$ Associated with the increasing survival rate in women with $\mathrm{BC}$, this fact has led to a large number of studies about quality of life related to health. ${ }^{14,15}$

However, the majority of the studies focuses on the evaluation of comorbidities and their effects on functionality and quality of life up to two years after surgery. ${ }^{16,17}$ These data should be complemented by longer studies of five and ten years following surgical treatment to obtain a better definition of the comorbidities and tof he impact on function and quality of life on this population. ${ }^{18-20}$

For the reasons presented before, this study has the primary objective of investigating a possible correlation between functionality and quality of life in patients with five-year survival who underwent surgical treatment for BC. The secondary goal is to evaluate surgical ipsilateral upper limb function and quality of life related to the type of surgery and pain.

\section{Methods}

This is a cross-sectional, observational analytical study with a quantitative approach, completed between February 
and April 2015 at the Physical Therapy ambulatory of Maternidade Carmela Dutra (MCD), in the city of Florianópolis, Brazil.

The study population consisted of women living in Florianópolis submitted to surgery for BC treatment according to the International Statistical Classification of Diseases and Related Health Problems 10th Revision (ICD-10), sectionC50 ('Malignant neoplasm of breast'), who were part of the Hospital Cancer Registry (HCR) at MCD between the years 2009 and 2010. The study excluded patients with other primary cancer types, metastasized cancer, and with an indication for nodulectomy surgery with no lymph node resection or sentinel lymph node biopsy. Subjects with cognitive impairments who were unable to complete the questionnaires were also excluded. The protocol was approved by the Ethics and Human Subject Research Committees at Universidade Estadual de Santa Catarina and MCD (CAAE 39722314.70000.0118). All participants signed an informed consent form as per the Helsinki Declaration and the Brazilian National Health Council Resolution n. 466, from December 2012. The Participants' identities and data confidentiality were protected.

\section{Data Collection}

All participants completed an initial survey containing: personal information, gynecological and obstetrics history, cancer history, daily habits and general questions related to the diagnosis and the physical therapy treatment for axillary cording. The participants then underwent a physical exam to investigate possible adherence, breast sensitivity through Semmes-Weinstein monofilament and ipsilateral arm lymphedema as per the Simplified Clinical Classification for Lymphedema. ${ }^{21}$ The McGill questionnaire was used to evaluate pain. ${ }^{22}$

Stature and body mass were verified by Sanny ${ }^{\circledR}$ (American Medical do Brasil Ltda, São Bernardo do Campo, Brazil) stadiometer and digital bioimpedance scale Ironman Segmental Body Composition Monitor (Tanita Corporation, 142, 1-Chome, Maeno-Cho, Itabashi-Ku, Tokyo, Japan) model BC-558 respectively. All measurements were performed barefoot, standing erect with the head aligned. The body mass index (BMI) was calculated according to World Health Organization (WHO) guidelines. ${ }^{23}$

The participants completed the Disabilities of Arm, Shoulder and Hand (DASH) and the Functional Assessment of Cancer Therapy - Breast plus Arm Morbidity (FACTB + 4) questionnaires, which were applied by a single examiner, and translated and culturally adapted for the Brazilian population. ${ }^{24,25}$

The DASH questionnaire is an instrument used to evaluate physical function. It verifies the impact of disability and the symptoms of upper extremities as a functional unit, and measures the difficulty or inability to perform specific activities. It consists of 30 items, which are divided in physical function, symptoms and social function. Each item is rated on a scale from 1-5. The total score ranges from $0-100$ points; the higher the score, the more severe the disability. ${ }^{24}$ Scores between the $25-75$ th quartiles are indicative of some disability, while scores lower than the 25th quartile represent minimal or no disability, and those greater than the 75th quartile indicate a high disability level. ${ }^{26}$

The FACTB +4 questionnaire was developed to assess quality of life in patients with breast cancer, and it was validated for the study population. ${ }^{27}$ It consists of 36 questions: 27 of them refer to quality of life in general; 9 relate to specific problems faced by women with breast cancer; and 4 relate to upper limb morbidity. This instrument is divided in six scales, which may be scored separately: physical wellbeing; social/family well-being; emotional well-being; functional well-being; breast cancer subscale; and arm subscale. Each one has scores that range from $0-4$. The total score ranges from 0 to 164 points, and high scores are associated with a better quality of life. ${ }^{28}$

\section{Statistical Analysis}

The statistical analyses were performed using the Statistical Package for the Social Sciences (IBM-SPSS, Inc., Chicago, IL, USA - licensed for use at Universidade Estadual de Santa Catarina ) software, version 20.0, and presented as descriptive statistics (mean and standard deviation) and frequencies. Data distribution was verified using the Shapiro-Wilk test, and the correlation was used to describe the degree and direction of the relationship between the variables. Pearson's correlation coefficient was used for the parametric variables, and Spearman's rank correlation coefficient for the non-parametric ones. Levene's test was used to analyze the homogeneity of variance. The comparison of the group means was done using the Student's $t$-test for parametric variables and the WilcoxonMann-Whitney test for non-parametric variables. The statistical significance was set at 5\% $(p<0.05)$.

\section{Results}

The mean time to complete both questionnaires was 30 minutes. Thirty patients were included; they had a mean age of $51.23( \pm 8.72$ ) years, and a mean BMI of $28.18( \pm 5.06)$, characterizing an overweight population. The majority of the patients were married or on a stable union (73.3\%), were caucasians (93.3\%), and had less than 8 years of schooling (60.0\%). Aside from that, $36.7 \%$ of them were ex-smokers, and $16.7 \%$ were smokers. Half of the participants did not practice any physical activity. - Table 1 shows the participants' demographics and habits.

The progression of the disease and the frequency of the complications are shown in - Table 2. Early stage diagnosis occurred in $83.3 \%$ of the participants, and the predominant histological type was ductal infiltrating (66.7\%). Conservative surgery was performed in $53.3 \%$ of the patients, and $70.0 \%$ of this group did not have either early or late breast reconstruction performed after surgery. The most frequent complications were: pain (50\%), adherence (33.3\%), nerve lesion (20.0\%) and lymphedema (13.3\%). Axillary cording was presented by $13.3 \%$ of the participants; half of them underwent treatment, and half progressed with spontaneous resolution with no specific interventions.

- Table 3 illustrates the mean, minimal, maximal and standard deviation data for the scores on both questionnaires 
Table 1 Participants' demographics and daily life activities

\begin{tabular}{|c|c|}
\hline Variables & Mean (SD) \\
\hline Age (years) & $51.23(8.72)$ \\
\hline BMI $(\mathrm{Kg} / \mathrm{m})$ & $28.18(5.06)$ \\
\hline Variables & N (\%) \\
\hline \multicolumn{2}{|l|}{ Marital status } \\
\hline Single & $1(3.3)$ \\
\hline Married/stable union & $22(73.3)$ \\
\hline Widow & $2(6.7)$ \\
\hline Separated & $5(16.7)$ \\
\hline \multicolumn{2}{|l|}{ Race } \\
\hline White & $28(93.3)$ \\
\hline African American & $1(3.3)$ \\
\hline Brown & $1(3.3)$ \\
\hline \multicolumn{2}{|l|}{ Educational level } \\
\hline$<8$ years & $18(60.0)$ \\
\hline$>8$ years & $12(40.0)$ \\
\hline \multicolumn{2}{|l|}{ Smoking status } \\
\hline Non-smoker & $14(46.7)$ \\
\hline Ex-smoker & $11(36.7)$ \\
\hline Smoker & $5(16.7)$ \\
\hline \multicolumn{2}{|l|}{ Physical Activity } \\
\hline Inactive & $15(50.0)$ \\
\hline Eventual & $4(13.3)$ \\
\hline Regular & $11(36.7)$ \\
\hline Unknown & $3(10.0)$ \\
\hline
\end{tabular}

Abbreviations: BMI, Body Mass Index; SD, Standard deviation. Note: $\mathrm{N}=30$.

and their individual domains. The mean score for the DASH was $41.03( \pm 22.27)$ points, and the total score for the FACTB +4 was $92.40( \pm 17.27)$, with scores of 19.8 and 19.6 for the additional concerns and the physical domains respectively.

There was a negative correlation between the DASH and the total score of the FACTB +4 , between the physical domain of the FACTB +4 and the DASH, and a high correlation coefficient between the DASH and the upper limb subscale of the FACTB +4 . Only the social/family domain of the $\mathrm{FACTB}+4$ did not show a significant statistical correlation with any other variables. The detailed correlation analysis and the more relevant data are presented in -Table 4 and - Fig. 1.

The analysis of the scores of both questionnaires and their domains in reference to the type of surgery performed (conservative or non-conservative) showed no statistical significant difference. However, when considering the presence or absence of pain, there was an influence on the score for both questionnaires $(p<0.05)(-$ Table 5$)$.
Table 2 Disease progression and frequency of post-surgery complications

\begin{tabular}{|c|c|}
\hline Variables & N (\%) \\
\hline \multicolumn{2}{|l|}{ Stage } \\
\hline Early & $25(83.3)$ \\
\hline Advanced & $2(6.7)$ \\
\hline Unknown & $3(10.0)$ \\
\hline \multicolumn{2}{|l|}{ Histology } \\
\hline Intraductal in situ & $1(3.3)$ \\
\hline Invasive Lobular & $5(16.7)$ \\
\hline Ductal infiltrative & $20(66.7)$ \\
\hline Other & $4(13.3)$ \\
\hline \multicolumn{2}{|l|}{ Surgery type } \\
\hline Conservative & $14(46.7)$ \\
\hline Non-conservative & $16(53.3)$ \\
\hline \multicolumn{2}{|l|}{ Reconstructive surgery } \\
\hline No & $21(70.0)$ \\
\hline Yes & $7(23.3)$ \\
\hline Unknown & $2(6.7)$ \\
\hline \multicolumn{2}{|l|}{ Scar adherence } \\
\hline No & $20(66.7)$ \\
\hline Yes & $10(33.3)$ \\
\hline \multicolumn{2}{|l|}{ Cording } \\
\hline No & $26(86.7)$ \\
\hline Yes & $4(13.3)$ \\
\hline \multicolumn{2}{|l|}{ Cording treatment } \\
\hline Treated & $2(50.0)$ \\
\hline Spontaneous recovery & $2(50.0)$ \\
\hline \multicolumn{2}{|l|}{ Nerve lesion } \\
\hline No & $24(80.0)$ \\
\hline Yes & $6(20.0)$ \\
\hline \multicolumn{2}{|l|}{ Lymphedema } \\
\hline No & $26(86.7)$ \\
\hline Yes & $4(13.3)$ \\
\hline \multicolumn{2}{|l|}{ Pain } \\
\hline No & $15(50.0)$ \\
\hline Yes & $15(50.0)$ \\
\hline
\end{tabular}

Note: $\mathrm{N}=30$.

\section{Discussion}

The correlation found between the DASH and the total score of the FACTB +4 was -0.634 , and the one between the DASH and the physical domain of the FACTB +4 was -0.720 . These findings indicate a moderate correlation among the variables. Still, a strong correlation ( $\mathrm{r}=-0.829$ ) between the arm subscale of the FACTB +4 and the DASH was observed, with 
Table 3 Mean, minimum and maximum scores and standard deviation of the FACTB +4 and DASH questionnaires

\begin{tabular}{|l|l|l|l|l|}
\hline Questionnaire (variable) & Minimum & Maximum & Mean & SD \\
\hline DASH & 2.00 & 76.00 & 41.03 & 22.27 \\
\hline FACTB +4 (physical) & 9.00 & 28.00 & 19.60 & 5.49 \\
\hline FACTB +4 (social/family) & 10.00 & 27.00 & 18.23 & 4.61 \\
\hline FACTB +4 (emotional) & 8.00 & 26.00 & 17.43 & 4.93 \\
\hline FACTB +4 (functional) & 3.00 & 26.00 & 17.13 & 4.46 \\
\hline FACTB +4 (AC) & 6.00 & 29.00 & 19.80 & 5.52 \\
\hline FACTB +4 (total) & 54.00 & 124.00 & 92.40 & 17.27 \\
\hline
\end{tabular}

Abbreviations: AC, additional concerns; DASH, Disabilities of Arm, Shoulder and Hand; FACTB +4 Functional Assessment of Cancer Therapy - Breast plus Arm Morbidity; SD, standard deviation.

$\mathrm{N}=30$.

Table 4 Correlation between the DASH and the FACTB +4 domains

\begin{tabular}{|l|l|l|l|}
\hline DASH & $\mathbf{R}$ & $\mathrm{R}^{2}$ & $p$ \\
\hline FACTB +4 (social/family) & 0.003 & 0.000 & 0.988 \\
\hline FACTB +4 (emotional) & -0.495 & 0.245 & 0.005 \\
\hline FACTB +4 (physical) & -0.720 & 0.518 & 0.000 \\
\hline FACTB +4 (functional) & -0.425 & 0.180 & 0.019 \\
\hline FACTB +4 (AC) & -0.462 & 0.213 & 0.010 \\
\hline FACTB +4 (total) & -0.634 & 0.401 & 0.000 \\
\hline FACTB +4 (arm subscale) & -0.829 & 0.687 & 0.000 \\
\hline
\end{tabular}

Abbreviations: AC, additional concerns; DASH, Disabilities of Arm, Shoulder and Hand; FACTB + 4 Functional Assessment of Cancer Therapy - Breast plus Arm Morbidity; r, correlation coefficient; $R^{2}$, coefficient of determination.

a coefficient of determination indicating that $68.7 \%$ of the score variability on the FACTB +4 arm subscale is related to the variability of the DASH.

The strong correlation between the DASH and the FACTB +4 arm subscale, and the moderate correlation between the DASH and the physical domain of the FACTB +4 could be explained by the fact that both are related to physical aspects and symptoms such as pain, edema, reduced ROM, rigidity and paresthesia of the ipsilateral arm. According to a study conducted by Fernandes, ${ }^{29}$ the DASH does not correlate with instruments of distinct concepts. Thus, when a correlation is performed between the DASH score and the total score of the FACTB +4 (which presents domains not related to physical function, such as emotional well-being and family/social well-being), there is a decrease in the magnitude of the correlation.
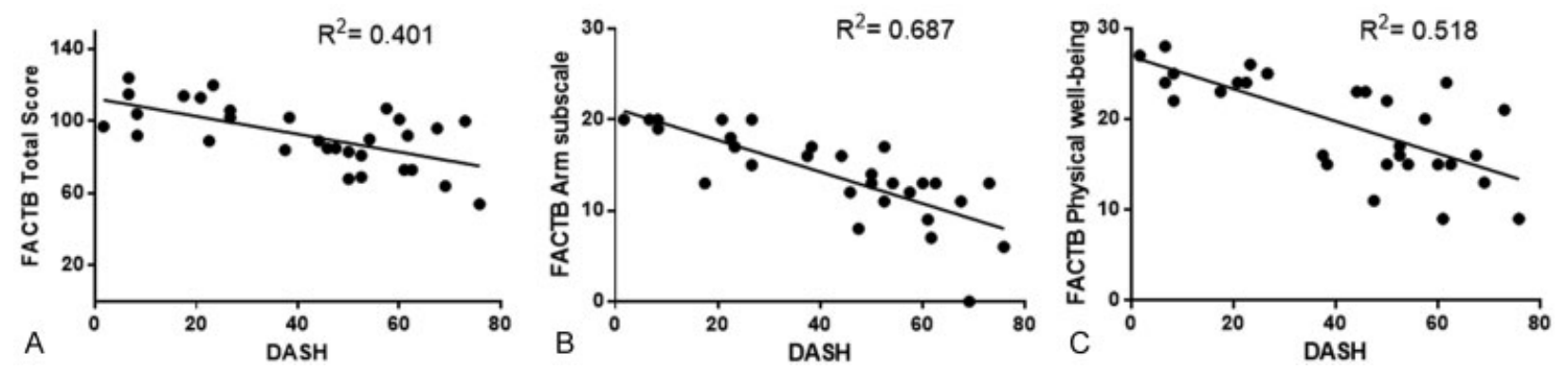

Fig. 1 Correlation between the DASH and FACTB +4 scores. (A) Pearson's correlation analysis between the DASH and the total score of the FACTB +4 . Correlation coefficient $=-0.634$; coefficient of determination $\left(R^{2}\right)=0.401 ; p=0.000$. (B) Spearman's coefficient correlation between the DASH and the arm subscale of the FACTB +4 . Correlation coefficient $=-0.829 ; R^{2}=0.687 ; p=0.000$. (C) Spearman's coefficient correlation between the DASH and the physical domain of the FACTB +4 . Correlation coefficient $=-0.720 ; R^{2}=0.518 ; p=0.000$. 
Table 5 Mean score values and comparison tests between the mean values on the FACTB +4 domains and on the DASH in reference to pain

\begin{tabular}{|l|l|l|l|}
\hline Questionnaire (variable) & $(\mathrm{SD})$ & $(\mathrm{SD})$ & $p$ \\
\hline & No pain $(\boldsymbol{N}=15)$ & With pain $(\boldsymbol{N}=15)$ & \\
\hline DASH & $25.87(19.42)$ & $56.19(12.07)$ & $0.000^{*}$ \\
\hline FACTB +4 (social/family) & $18.53(4.96)$ & $17.93(4.40)$ & 0.728 \\
\hline FACTB +4 (emotional) & $19.60(3.98)$ & $15.27(4.95)$ & $0.014^{*}$ \\
\hline FACTB +4 (physical) & $22.87(4.50)$ & $16.33(4.38)$ & $0.001^{*}$ \\
\hline FACTB + 4 (functional) & $18.87(3.42)$ & $15.40(4.81)$ & $0.032^{*}$ \\
\hline FACTB + 4 (AC) & $21.80(5.29)$ & $17.80(5.16)$ & $0.045^{*}$ \\
\hline FACTB + 4 (total) & $101.87(14.94)$ & $82.93(14.23)$ & $0.001^{*}$ \\
\hline FACTB + 4 (arm subscale) & $16.33(4.54)$ & $12.06(4.47)$ & $0.015^{*}$ \\
\hline
\end{tabular}

Abbreviations: AC, additional concerns; DASH, Disabilities of Arm, Shoulder and Hand; FACTB + 4 Functional Assessment of Cancer Therapy - Breast plus Arm Morbidity; SD, Standard deviation.

Note: ${ }^{*}$ Significance level of $5 \%(p<0.05)$.

The subjects presented, on average, moderate upper limb dysfunction (41.3 points) according to the DASH, and decreased quality of life (92.04 points) according to the FACTB +4 . These results are similar to those of other studies ${ }^{17,30,31}$ that showed a significant correlation between the morbidity of the arm and reduced quality of life after BC treatment. The present study also confirms the findings of the study conducted by Fangel et al, ${ }^{12}$ which showed a moderate correlation between the physical domain on the 30-item European Organization for Research and Treatment of Cancer Core Quality of Life Questionnaire ( EORTC-QLQ-C30) and function.

In agreement with other study findings, ${ }^{32}$ but diverging from other authors ${ }^{20}$ as well, when the questionnaire scores were analyzed according to the type of surgery (conservative or non-conservative), there was no significant difference. This could be explained by the fact that the extent of the procedure (with or without lymph node dissection) could have more influence on comorbidities than the type of surgery itself. ${ }^{32,33}$ The presence of positive lymph nodes indicates more aggressive surgical procedures, systemic therapy and longer radiation treatment, which contributes to increased functional impairment. ${ }^{34}$

On the other hand, when the comparison is performed considering the presence or absence of pain on the ipsilateral $\mathrm{arm}$, there was a significant difference on the total score of the FACTB +4 (101.87 no pain; 82.93 with pain) and, above all, on the DASH (25.87 no pain; 56.19 with pain). Some studies mention pain as the most incident comorbidity directly related to the worsening of upper extremity function and/or a worse quality of life. $5,16,33,34$ The onset of pain may occur immediately after surgery, or it may occur as a consequence of radiation, ${ }^{5}$ and the pain can endure for a long period of time. The intercostobrachial nerve lesion is considered the main cause of pain, ${ }^{33}$ and some other causes may be myofascial pain syndrome and axillary cord. ${ }^{8,35}$ Milder symptoms, such as pain and paresthesia, are common between two and five years after the axillary lymphadenectomy. ${ }^{36}$
The present study showed a lower percentage of comorbidities (pain, adherence, nerve lesion and lymphedema) related to $\mathrm{BC}$ treatment compared with those found in the literature. ${ }^{25}$ One of the main reasons for this finding is that most studies focus on comorbidities up to two years postsurgery, ${ }^{9,17,34,37}$ and rarely on the data about the prevalence of comorbidities after five or more years. ${ }^{25,36}$

Apart from the surgical treatment, another important factor associated with upper limb morbidities is radiation. Radiation causes adverse effects such as pain, fatigue, fibrosis, sensitive changes and cutaneous impairment, like radiodermititis. ${ }^{5,19}$ Sensitivity changes are associated with the intercostobrachial nerve lesion caused during the surgical procedure, or caused by other therapies, such as radiation. ${ }^{32}$

Sensorial damage and pain may influence the accomplishment of functional tasks due to the inhibitory muscle effect. ${ }^{38}$ Levy et $\mathrm{al}^{34}$ suggested that pain, sensitivity changes, fatigue and weakness may coexist and have a significant cumulative effect, contributing to long-term functional morbidity. Furthermore, changes on the axillary region due to the dissection of the lymph nodes, as well as scar retraction, tissue fibrosis, stiffness, thoracic muscle hypotrophy and hypomobility contribute to decreased shoulder ROM and function. ${ }^{38,39}$ According to Fangel et $\mathrm{al}^{12}$ the dysfunctions resulting from $\mathrm{BC}$ treatment lead to changes in the routines of the patients, at the family and professional levels, which may affect their selfesteem and, consequently, their quality of life.

Many symptoms and dysfunctions are not measured by the conventional clinical methods. The use of questionnaires completes this gap, for they contribute to the recognition of functional and emotional problems, aid in the description of a group and in the evaluation of the results of an intervention, and that refines the clinical results. ${ }^{14,40}$ Moreover, questionnaires are low-cost, convenient and easy tools that allow the identification of the needs of the patients; they also assist the physical therapist in terms of rehabilitation planning and selection of the adequate therapies. ${ }^{12}$ 
Even though the sample size was not calculated in advance, the power of all correlations with $\alpha=0.05$ was $95 \% .{ }^{41}$

The main limitation of the present study was the lack of follow-up during the five-year survival, which would enable a yearly report of the quality of life and function in this group. Also, the results refer to a group treated at a highly recognized facility, which may not reflect the general population.

\section{Conclusion}

There was a moderate negative correlation between the total scores of the DASH and FACTB +4 questionnaires and a strong correlation between the DASH and the arm subscale of the FACT +4 .

The participants presented on average regular function based on the DASH, and decreased quality of life based on the FACTB +4 . Those who presented pain had worse ipsilateral upper limb function and worse quality of life compared with the participants with no pain. There was no significant difference between groups when considering the type of surgery performed.

\section{Acknowledgments}

The study was conducted at Universidade do Estado de Santa Catarina, Maternidade Carmela Dutra (Florianópolis), with funds from Programa de Educação pelo Trabalho para a Saúde/Vigilância em Saúde (PET/VS) - 2013/2015, of the Brazilian Health and Education Ministries.

\section{References}

1 World Health Organization [Internet]. Breast cancer: prevention and control. 2014 [cited 2014 Oct 26]. Available from: <http:// www.who.int/cancer/detection/breastcancer/en/>

2 Torre LA, Bray F, Siegel RL, Ferlay J, Lortet-Tieulent J, Jemal A. Global cancer statistics, 2012. CA Cancer J Clin 2015;65(02):87-108

3 Brasil. Ministério da Saúde. Instituto Nacional de Câncer José Alencar Gomes da Silva (INCA) [Internet]. . Tipos de câncer: mama. 2014 [citado 2014 Out 08]. Disponível em: <http://www2.inca. gov.br/wps/wcm/connect/tiposdecancer/site/home/mama/ cancer_mama>

4 Brasil. Ministério da Saúde. Instituto Nacional de Câncer José Alencar Gomes da Silva. Coordenação de Prevenção e Vigilância [Internet]. Estimativa 2014: incidência de câncer no Brasil. Rio de Janeiro: INCA; 2014 [citado 2014 Out 26]. Disponível em: http://www.saude.sp.gov.br/resources/ses/perfil/gestor/homepage/outros- destaques/estimativa-de-incidencia-de-cancer-2014/estimativa_cancer_24042014.pdf

5 Bezerra TS, Rett MT, Mendonça ACR, Santos DE, Prado VM, De Santana JM. Hipoestesia, dor e incapacidade no membro superior após radioterapia adjuvante no tratamento para câncer de mama. Rev Dor. 2012;13(04):320-326

6 Assis MR, Marx AG, Magna LA, Ferrigno ISV. Late morbidity in upper limb function and quality of life in women after breast cancer surgery. Braz J Phys Ther 2013;17(03):236-243

7 Nascimento SL, Oliveira RR, Oliveira MMF, Amaral MTP. Complicações e condutas fisioterapêuticas após cirurgia por câncer de mama: estudo retrospectivo. Fisioter Pesqui. 2012;19(03): 248-255
8 Yeung WM, McPhail SM, Kuys SS. A systematic review of axillary web syndrome (AWS). J Cancer Surviv 2015;9(04):576-598

9 Barranger E, Dubernard G, Fleurence J, Antoine M, Darai E, Uzan S. Subjective morbidity and quality of life after sentinel node biopsy and axillary lymph node dissection for breast cancer. J Surg Oncol 2005;92(01):17-22

10 Schreiber KL, Martel MO, Shnol H, et al. Persistent pain in postmastectomy patients: comparison of psychophysical, medical, surgical, and psychosocial characteristics between patients with and without pain. Pain 2013;154(05):660-668

11 Organização Mundial da Saúde. Direção Geral da Saúde [Internet]. Classificação internacional de funcionalidade, incapacidade e saúde. Lisboa; 2004 [citado 2014 Out 10]. Disponível em: <http://www.inr.pt/uploads/docs/cif/CIF_port_\%202004.pdf>

12 Fangel LMV, Panobianco MS, Kebbe LM, Almeida AM, Gozzo TO. Qualidade de vida e desempenho de atividades cotidianas após tratamento das neoplasias mamárias. Acta Paul Enferm 2013; 26(01):93-100pp.

13 Lotti RCB, Barra AA, Dias RC, Makluf ASD. Impacto do tratamento de câncer de mama na qualidade de vida. Rev Bras Cancerol 2008; 54(04):367-371

14 Majewski JM, Lopes ADF, Davoglio T, Leite JCC. Quality of life of women recovering from breast cancer after being subjected to mastectomies compared with those who had conservative surgery: a review of the literature. Cien Saude Colet 2012;17(03): 707-716

15 Ganz PA. Assessing the quality and value of quality-of-life measurement in breast cancer clinical trials. J Natl Cancer Inst 2011; 103(03):196-199

16 Velloso FSB, Barra AA, Dias RC. Functional performance of upper limb and quality of life after sentinel lymph node biopsy of breast cancer. Rev Bras Fisioter 2011;15(02):146-153

17 Rietman JS, Geertzen JHB, Hoekstra HJ, et al. Long term treatment related upper limb morbidity and quality of life after sentinel lymph node biopsy for stage I or II breast cancer. Eur J Surg Oncol 2006;32(02):148-152

18 Nascimento de Carvalho F, Bergmann A, Koifman RJ. Functionality in women with breast cancer: the use of International Classification of Functioning, Disability and Health (ICF) in clinical practice. J Phys Ther Sci 2014;26(05):721-730

19 Yang EJ, Park WB, Seo KS, Kim SW, Heo CY, Lim JY. Longitudinal change of treatment-related upper limb dysfunction and its impact on late dysfunction in breast cancer survivors: a prospective cohort study. J Surg Oncol 2010;101(01):84-91

20 Arndt V, Stegmaier C, Ziegler H, Brenner H. Quality of life over 5 years in women with breast cancer after breast-conserving therapy versus mastectomy: a population-based study. J Cancer Res Clin Oncol 2008;134(12):1311-1318

21 Miller AJ, Bruna J, Beninson J. A universally applicable clinical classification of lymphedema. Angiology 1999;50(03):189-192

22 Castro CES. A formulação linguística da dor: versão brasileira do questionário McGill de dor [dissertação]. São Carlos: Universidade Federal de São Carlos; 1999

23 World Health Organization. Obesity: preventing and managing the global epidemic: Report of a World Health Organization Consultation. Geneva: WHO; 2000. (WHO Obesity Technical Report Series, 284).

24 Orfale AG, Araújo PMP, Ferraz MB, Natour J. Translation into Brazilian Portuguese, cultural adaptation and evaluation of the reliability of the Disabilities of the Arm, Shoulder and Hand Questionnaire. Braz J Med Biol Res 2005;38(02):293-302

25 Paim CR. Complicações e qualidade de vida em pacientes submetidas a biopsia de linfonodo sentinela ou a linfadenectomia axilar no câncer de mama [dissertação]. Belo Horizonte: Universidade Federal de Minas Gerais; 2008

26 Thomas-Maclean RL, Hack T, Kwan W, Towers A, Miedema B, Tilley A. Arm morbidity and disability after breast cancer: new directions for care. Oncol Nurs Forum 2008;35(01):65-71 
27 Michels FAS, Latorre MRDO, Maciel MS. Validação e reprodutibilidade do questionário FACT-B+4 de qualidade de vida específico para câncer de mama e comparação dos questionários IBCSG, EORTC-BR23 e FACT-B+4. Cad Saude Colet 2012;20(03):321328

28 Oliveira IS, Costa LCM, Manzoni ACT, Cabral CMN. Assessment of the measurement properties of quality of life questionnaires in Brazilian women with breast cancer. Braz J Phys Ther 2014;18(04):372-383

29 Fernandes MR. Correlation between functional disability and quality of life in patients with adhesive capsulitis. Acta Ortop Bras 2015;23(02):81-84

30 Góis MC, Furtado PR, Ribeiro SO, Lisboa LL, Viana ESR, Micussi MTABC. Amplitude de movimento e medida de independência funcional em pacientes mastectomizadas com linfadenectomia axilar. Rev Ciênc Méd (Campinas) 2012;21(1-6):111-118

31 Hayes SC, Johansson K, Stout NL, et al. Upper-body morbidity after breast cancer: incidence and evidence for evaluation, prevention, and management within a prospective surveillance model of care. Cancer 2012;118(8, Suppl)2237-2249

32 Albuquerque VT, Bezerra LMA, D’Oliveira GDF, Melo GF. Funcionalidade de membros superiores em mulheres após cirurgia para câncer de mama [monografia]. . Goiânia: Pontifícia Universidade Católica de Goiás; 2013
33 Lahoz MA, Nyssen SM, Correia GN, Garcia APU, Driusso P. Capacidade funcional e qualidade de vida em mulheres pósmastectomizadas. Rev Bras Cancerol 2010;56(04):423-430

34 Levy EW, Pfalzer LA, Danoff J, et al. Predictors of functional shoulder recovery at 1 and 12 months after breast cancer surgery. Breast Cancer Res Treat 2012;134(01):315-324

35 Stubblefield MD, Keole N. Upper body pain and functional disorders in patients with breast cancer. PM R 2014;6(02):170-183

36 Warmuth MA, Bowen G, Prosnitz LR, et al. Complications of axillary lymph node dissection for carcinoma of the breast: a report based on a patient survey. Cancer 1998;83(07):1362-1368

37 Kootstra J, Hoekstra-Weebers JEHM, Rietman H, et al. Quality of life after sentinel lymph node biopsy or axillary lymph node dissection in stage I/II breast cancer patients: a prospective longitudinal study. Ann Surg Oncol 2008;15(09):2533-2541

38 Borstad JD, Szucs KA. Three-dimensional scapula kinematics and shoulder function examined before and after surgical treatment for breast cancer. Hum Mov Sci 2012;31(02):408-418

39 Camargo MC, Marx AG. Reabilitação física no câncer de mama. São Paulo: Roca; 2000

40 Osoba D. Health-related quality of life and cancer clinical trials. Ther Adv Med Oncol 2011;3(02):57-71

41 Hulley SB, Cummings SR, Browner WS, Grady DG. Delineando a pesquisa clínica. 4a ed. Porto Alegre: Art Med; 2015 